Z Badań nad Książką i Księgozbiorami Historycznymi 2019. T. specjalny: Dla Niepodległej The Studies into the History of the Book and Book Collections 2019. Special issue: For an Independent Poland

\title{
Public libraries for children in Poland 1918-1939 - assumptions and reality
}

\begin{abstract}
The article attempts to reconstruct the assumptions and ideas that influenced the creation and organization of public libraries for children in the interwar period in Poland. On the basis of press articles and archival materials, two models of child reader support were described (Łódź model - creation of book rental, and Warsaw model - creation of readers), as well as foreign models (French and American) used by the founders of these institutions, taken over by the emerging Polish libraries. In the final part, there is a reference to war and just a post-war history of children's libraries. The names of the creators of the idea of children's librarianship in the Second Polish Republic were recalled (among others, Helena Radlińska, Jan Augustyniak, Maria Gutry, Jadwiga Filipkowska-Szemplińska and others).
\end{abstract}

Key words: Public libraries - libraries for children - Poland -1918-1939 - history.

„Z Badań nad Książką i Księgozbiorami Historycznymi” - Udział zagranicznych recenzentów w ocenie publikacji; Stworzenie anglojęzycznej wersji wydawniczej publikacji; Digitalizacja tomów archiwalnych rocznika w celu zapewnienia otwartego dostępu do nich przez Internet oraz wdrożenie i utrzymanie cyfrowej platformy redakcyjnej - zadanie finansowane w ramach umowy $\mathrm{nr}$ 653/P-DUN/2019 ze środków Ministra Nauki i Szkolnictwa Wyższego przeznaczonych na działalność upowszechniającą naukę. 
Development of the first children's libraries is historically related to those for the adults. However, one cannot speak about simultaneous birth of them both. Regardless of the place, first, the adults were cared for, then school youth, and finally children. Development of public libraries in the $19^{\text {th }}$ and at the beginning of the $20^{\text {th }}$ century was mostly related to dissemination of education, decrease of illiteracy, and the need for filling free time. Additionally, they were soon perceived as a perfect tool for the immigrants assimilation, in particular in the United States of America. Polish librarians were aware of American achievements in the organization of children's libraries ${ }^{1}$. Jan Augustyniak, an organizer of the municipal network of libraries in Łódź, wrote:

Stany Zjednoczone Ameryki Północnej, które i pod względem organizacji i wyposażenia bibliotek przodują całemu światu, posunęly sprawę bibliotek dziecięcych o krok dalej, kładąc nacisk na komfortowe, pod względem umeblowania, urządzenie bibliotek dla dziatwy, na bogaty księgozbiór, złożony z dobrych i pięknych tak pod względem treści, jak i zewnętrznej szaty książek, na daleko idącą swobodę dla młodych czytelników przy wyborze książek, z prawem bezpośredniego ich wyboru z szaf bibliotecznych, wreszcie na ograniczenie możliwości korzystania z biblioteki na miejscu, w lokalu biblioteki².

[The United States of America, the world leader in libraries organization and equipment, moved the matter of children's libraries a step forward, emphasizing comfortable furnishing of children's libraries, their rich collections consisting of books good and beautiful in regard of both contents and form, far-reaching freedom of the young readers in book selection, with a right of choosing them from library shelves, and finally limitation of the possibility of using the library on site, on its premises.]

However, the direct model for Warsaw libraries for children was the Paris facility "L'Heure Joyeuse"3. It was opened on November 12, 1924, with the support of the American Book Committee on Children's Libraries. Its organization and services were to be a model for other libraries. It was assumed to be the documentation centre of children book and the centre of pedagogical and vocational education of future librarians. It was opened between 9.30 a.m. and 7.00 p.m. for children aged 6-16 from all social groups, with free access to the shelves full of colourfully bound books. It was a coeducational facility, which caused protests and even postulates to separate boys from girls with a barrier. The Paris library was highly successful, the reasons of its popularity should be first sought in different than before perception of a child and his/

\footnotetext{
1 J. Augustyniak, Nowe formy organizacji czytelnictwa w zastosowaniu do miejskich bibliotek dziecięcych, "Dziennik Zarządu m. Łodzi”" 1928, no 18 (445), pp. 289-291.

2 Ibidem, p. 290.

3 Ha.Fa. [Handelsman Helena], Czytelnia dla dzieci w Paryżu, "Bluszcz. Pismo tygodniowe ilustrowane dla kobiet" 1925, no 2, p. 39. See also: M.N. Maack, L'Heure Joyeuse, the First Children's Library in France: Its Contribution to a New Paradigm for Public Libraries, "The Library Quarterly: Information, Community, Policy" 1993, vol. 63, no 3, pp. 257-281.
} 
her relation with an adult. Its detailed organization and working methods are known due to the preserved report of Maria Gutry, who visited this facility in July $1928^{4}$. She described its activities in detail on 13 pages of typewriting. She paid a great deal of attention to book classification and cataloguing, readers registering, lending technique, and methods of work with children. Interesting is also her opinion concerning an atmosphere in the library:

nastrój biblioteki - to daleko idąca swoboda, nie ma żadnych nakazów, czy zakazów, dzieci robią co chcą, rozmawiają nawet czasem dosyć głośno - robi wrażenie, jakby przychodziły do biblioteki żeby się spotkać, podyskutować o książkach, a nie żeby czytać. Bibliotekarki nie robią im zupełnie uwag, dużo czasu zużywają na omawianie książek z poszczególnymi czytelnikami. Stosunek do dzieci jest koleżeński, podają im ręce na powitanie, dowcipkują i śmieją się razem z dziećmi ${ }^{5}$.

[an atmosphere in the library - it is a far-reaching freedom. There are no orders or restrictions, children do what they want to, sometimes they talk quite loud. It seems as they come to the library to meet each other, to discuss books, not to read. The librarians do not admonish them, they spend a lot of time discussing books with individual readers. Their attitude towards children is friendly, they shake hands with them, make jokes, and laugh together with children.] The process of developing public libraries for children in Poland after regaining independence in 1918 was realized in different contexts. Two different municipal centers were marked on the country map, where first facilities of that kind had been organized, i.e. Łódź and Warszawa. Commonly available, free of charge libraries for the youngest readers were organized in these two cities in a deliberate and planned way. However, one should consider that these initiatives did not emerge in a vacuum. They were preceded with a long chain of activities realized either during the partition or just after regaining independence, by public and educational institutions of different kinds, associations and other charity organizations or private persons. Polska Macierz Szkolna [Polish Educational Society], Towarzystwo Czytelni Ludowych [People's Libraries Society], Towarzystwo Szkół Ludowych [People's Schools Society], Warszawskie Towarzystwo Dobroczynności [Warsaw Charitable Society] with its dedicated Wydział Czyteln [Department of Reading Rooms], Towarzystwo Biblioteki Publicznej [Public Library Society], Towarzystwo Czytelń Miasta Warszawy [Warsaw Reading Rooms Society], Towarzystwo Krzewienia Oświaty in Łódź [Education Society], and the postwar Towarzystwo Bibliotek dla Dzieci [Libraries for Children Society], transformed into Towarzystwo Przyjaciół Bibliotek Dziecięcych [Society of Friends of Children's Libraries] were (among others) which particularly

4 M. Gutry, Panu Czerwijowskiemu sprawozdanie z mojej pierwszej podróży bibliotekarskiej. Dn. $10 \mathrm{~V}$ 29. Document (typescript) available at the Children's Book Museum, the Warsaw Public Library, sign. B.027.625.

5 Ibidem, p. 11. 
contributed to promotion of the Polish book, including that for children. Łódzka Wypożyczalnia Ksiażek Haliny i Felicji Pieńkowskich [Halina \& Felicja Pieńkowskie Library in Łódź] should be mentioned as a private initiative of that kind.

It should be remembered that the population living in the Polish territories either during the partition or after regaining independence was multicultural and multilingual. For instance, population structure in Łódź in 1921 consisted of $61,9 \%$ of the Poles, $30,7 \%$ of the Jews, and $7 \%$ of the Germans. Therefore, the youngest readers needed not only Polish, but also Jewish, German, or other books. The library for Jewish children was established in Łódź just in 1890, in 1913 the management board of the Association of Jewish Teachers opened a library for the youth, and in 1916 women from the Jewish intelligentsia established a free of charge library called "Zorza" ${ }^{6}$ [Aurora]. The People's Schools Society managed 163 libraries for school children and youth in the years 19141915. Karol Szaniecki and Antoni Ludwiczak, a priest and the secretary general of the Society, wrote the appeal concerning mostly books sent to field hospitals for injured soldiers. They appealed not to forget "about children whose fathers died or are at war and cannot care for them", and underlined that "Children must be given the Polish primer or the Polish book with pictures so that they do not go wild or do not forget to feel in Polish"' . Therefore, a Polish book for children was cared for in different dimensions.

Other factors influencing the development of first libraries for children include psychological and pedagogical trends of that time, development of children literature, and general development of public libraries organized by local authorities ${ }^{8}$. As for the latter, the strongest impulse for organization of public libraries for children was undoubtedly the resolution of the Municipal Council of Łódź concerning compulsory schooling of June 30, 1919, which entered into force from the school year 1919/1920.

Development of the national education system, together with the organization of fundamental structures of administration of the reborn State, development of a unified education system from the beginning, integrating experiences and systems of three partitions, influenced the development of libraries. The reduction of illiteracy was an extremely important problem. Despite the introduction

6 I. Nagórska, Początki czytelnictwa dzieci i młodzieży w Łodzi, "Bibliotekarz" 1972, no 11-12, pp. 350-356.

7 J. Wróblewski, Działalność Towarzystwa Czytelń Ludowych w Poznaniu na rzecz ofiar wojny (1914-1918), "Bibliotekarz" 1973, no 4, p. 110.

8 D. Grabowska, Rozwój sieci bibliotek dziecięcych w Polsce. Wybrane problemy, [in:] Megabiblioteki. Wybrane tendencje w bibliotekarstwie publicznym, ed. by D. Pietrzkiewicz, E.B. Zybert, Warszawa 2015, p. 50. 
of compulsory schooling, $20 \%$ of children aged 7-10 were not going to school ${ }^{9}$. The first population census in 1921 revealed that $37,2 \%$ of the population could not read nor write, and the illiteracy in rural areas amounted to $60 \%{ }^{10}$.

\section{Assumptions}

It was understood relatively quickly that within a new political system it was impossible to run cultural and educational activities with social forces, based only on voluntary fees and the volunteers' work. The following assumptions were pursued by the organizers of public libraries for children:

- children's interest in the book, including the one other than a school textbook; free access to carefully selected, diversified, and possibly rich book collections;

- completion of schooling deficiencies, filling up free time, access to the book free of charge, development of free of charge reading rooms for children,

- creating adequate conditions, atmosphere for association with the book,

- promotion of the joy of reading.

The main goal was the care for children's well being and culture, introduction to reading, independence, responsibility, learning of respect for the common $\operatorname{good}^{11}$.

Educational goals were also important - intellectual development, character development, and education of a future citizen of the Republic of Poland, loyal to the law, responsible for him/herself and his/her actions. Among others, the library council in children's libraries was to serve that ${ }^{12}$.

Rdzeń jednak - to współżycie dzieci z biblioteką i książką - to praca wychowawcza. Biblioteki warszawskie są jeszcze za młode, żeby mogły wyrobić sobie swoiste metody, tymczasem przeprowadzają próby różnych prac stosowanych zagranicą

[The core, however - is the coexistence of children, the library and the book - this is educational work. Warsaw libraries are still too young to develop their own methods, therefore they experiment with different methods applied abroad]

as wrote M. Gutry in 1928 in the manual concerning organization of libraries for children and youth, published by Polski Komitet Opieki nad Dzieckiem

9 J. Kołodziejska, Publiczne biblioteki samorządowe w okresie międzywojennym, Warszawa 1967, p. 29.

$10 \quad$ Ibidem, p. 34.

11 J. Bornsteinowa, Biblioteki dla dzieci, "Praca szkolna. Dodatek miesięczny do Głosu Nauczycielskiego poświęcony sprawom pedagogiczno-dydaktycznym w związku z praktyką szkolną" 1927, no 5, p. 177 and M. Gutry, Biblioteka Wzorowa dla dzieci, [in:] Biblioteki dla dzieci w Polsce, Warszawa 1934, p. 9.

12 Ibidem, p. 178 
[Polish Committee for Child Care $]^{13}$. Jadwiga Bornsteinowa emphasized earlier that "the better we will educate children, the better citizens this country will obtain"14. Public libraries for children being developed formed the part of a trend of non-formal education, as well as the model of citizen education:

Troska o dziecko, nie tylko w obrębie szkoły skłania różne organizacje do tworzenia komórek pracy pozaszkolnej, a dziecięca biblioteka publiczna powinna i w tej gałęzi pracy kulturalnej znaleźć odpowiednie miejsce ${ }^{15}$.

[A care for children, not only in a school, encourages different organizations to establish units of out-of-school work, and a public children's library should find its place also in this branch of cultural work.]

\section{Realizations}

As mentioned in the introduction, the idea of opening public libraries for children had been developed independently and differently in two large municipal centers. Undoubtedly Łódź has a priority in this regard.

\section{Łódź}

The Łódź authorities accepted the plan of "The model municipal network of libraries" in 1921, initiated by J. Augustyniak. The models the author referred to while developing his concept of a library network are difficult to reconstruct. Undoubtedly, he found a stable funding for libraries the most important. Only the municipal authorities were able to bear the costs of their functioning. He wrote:

Łódź pierwsza w Polsce rozstrzygnęła kwestię bibliotek i czytelnictwa w sensie radykalnym. Samorząd łódzki zdecydował już przed dwoma laty traktować sprawę ustalenia bytu bibliotek, jako jedno z głównych swych zadań. Ze względu więc na znaczenie, jakie innowacja ta dla sprawy czytelnictwa w Polsce posiada, oraz uwzględniając pośrednio zapytania różnych miast i instytucji - notujemy kilka poniższych uwag. Kwestią najważniejszą, jaka się inicjatorom przekazania spraw bibliotek gminie nasuwała do rozstrzygnięcia, była myśl, aby w nowych warunkach politycznych oprzeć sprawę istnienia i rozwoju bibliotek na zdrowych podstawach i nie powtarzać tych błędów, które się przyczyniły do katastrofalnych upadków i dezorganizacji książnic polskich. Taką najważniejszą kwestią była - podstawa finansowa bibliotek $^{16}$.

13 M. Gutry, Rola i organizacja bibliotek dla dzieci i młodzieży, Warszawa 1928, p. 13.

14 J.B. [J. Bornsteinowa], Biblioteka dla dzieci w Warszawie, "Bluszcz. Pismo tygodniowe ilustrowane dla kobiet" 1926, no 6, p. 162.

15 M. Gutry, Rola i organizacja bibliotek..., p. 3.

16 J. Augustyniak, Biblioteki miejskie w Lodzi. Dwuletnia opieka samorządu, "Dziennik Zarządu m. Łodzi"1924, no 48 (271), p. 1. 
[Łódź - as the very first city in Poland - radically resolved the issue of libraries and reading. The Łódź authorities decided just two years ago to perceive the libraries' existence as one of its main goals. Regarding the significance of this innovation for the matter of reading in Poland, as well as - indirectly - the questions from different cities and institutions, we present below a couple of remarks. The most important question to be resolved, as perceived by the initiators of transferring libraries to local authorities, was the idea to base the libraries' existence and development on healthy grounds in a new political situation, and do not repeat the mistakes which contributed to catastrophic falls and disorganization of Polish libraries. The most important issue was financing of the libraries.]

The plan assumed organization of a three-level municipal network, including a central public library, and libraries for the adults and for children. The latter were intended for school children aged 7-14. The goal of this initiative was to provide children with the good book, and to develop a network of public reading rooms independent of a school system. The facilities were to be located all over the city, with particular focus on working-class districts. The First Municipal Library of children books started its activity on March 18, 1922 at Piotrkowska 223 str. This date should be actually perceived as the beginning of public libraries for children in Poland. Another facility at Rybna 14 str. was opened in October that year ${ }^{17}$. Their development had been dynamic until 1928 when the economic crisis ended the organization of new facilities. There were six municipal libraries for children and youth in Łódź until 1939. It was estimated that at least 40 similar libraries had to be opened, calculating approximately 1500 children per library, and 60000 children under compulsory schooling in that time in Łódź ${ }^{18}$. Looking for premises out of schools for public libraries was a very important task, because the readers were to be schoolage young people, not only pupils. It was obvious that many children did not attend school. Regardless of these assumptions, only two libraries were located on individual premises, the rest were in school buildings, due to lacking funds for rent. Libraries for children possessed more than 36000 books at the end of 1933, and were visited by more than 7700 readers, more than 274000 books were lent ${ }^{19}$. They collected books in Polish, except the $2^{\text {nd }}$ Library, which owned also Jewish ones ${ }^{20}$. Despite the crisis at the beginning of the

\footnotetext{
17 I. Augustyniakowa, Biblioteki dziecięce w Lodzi. Historia i stan obecny, [in:] Biblioteki dla dzieci w Polsce, Warszawa 1934, p. 4.

18 J. Augustyniak, Nowe formy organizacji czytelnictwa..., p. 289. The author wrote here about the need of 30 children's libraries in Łódź, while his wife Irena Augustyniakowa, responsible for children's libraries, mentioned 40 of them, which is closer to mathematic calculation, see I. Augustyniakowa, Biblioteki dziecięce w Łodzi. Historia i stan obecny, "Bibliotekarz. Biuletyn Biblioteki Publicznej m. st. Warszawy poświęcony sprawom bibliotek publicznych" 1934-1935, no 3-4-5, p. 30.

19 I. Augustyniakowa, Biblioteki dziecięce $w$ Łodzi..., p. 5.

20 W 50-lecie powstania pierwszej w Polsce biblioteki publicznej dla dzieci i młodzieży 1922 1972. Katalog wystawy, [compiled by I. Nagórska], Łódź 1972, p. 4.
} 
30s., the libraries did not limit their activities to acquisition, indexing and lending books, they also realised different forms of work with the readers, such as: storytelling, drawing contests, short speeches. The library council had also been developed, and the reading surveyed. The librarians permanently cared for cooperation with schools, which was quite poor. As Iwona Kaczmarek writes: "The basic form of offering collections was lending, the reading rooms were available only in $1^{\text {st }}$ and $2^{\text {nd }}$ Libraries, due to housing conditions" ${ }^{21}$. The $6^{\text {th }}$ Library was specific, as it was organized like the American ones, and as the only one in Łódź at the beginning it offered its collections on site only. It was an experimental facility, its opening was preceded with an excursion of Łódź librarians to Warszawa, where they were informed about organization and working methods of Biblioteka Wzorowa [Model Library] 22. However, "after six years of functioning, due to the change of location, the reading room was closed and lending services were offered only"23.

Despite this, the activity of Łódź libraries for children was highly appreciated, as confirmed by Helena Radlińska opinion, who wrote: "The most prominent place among public libraries for the youth belongs to three municipal Łódź libraries. [...] The level of [their] work holds up to the best foreign models" ${ }^{24}$.

The library network in Łódź ceased during World War II, they were closed, and their collections destroyed.

\section{Warszawa}

A few different non-governmental organizations undertook the construction of public libraries for children in Warsaw after regaining independence.

J. Bornsteinowa presented the project of children's library at Biblioteka Publiczna [the Public Library, BP] during the meeting of Związek Bibliotekarzy Polskich [the Polish Librarian' Union, ZBP] on March 5, 1925 $5^{25}$. The organizational meeting took place on March 10, and the first library-reading room for children was opened in Warsaw on March 22, 1925, in the auditorium of journals reading room of the Public Library at Koszykowa 26 str. ${ }^{26}$ Faustyn

21 I. Kaczmarek, Biblioteki oświatowe i publiczne w Lodzi w dwudziestoleciu międzywojennym,

“Acta Universitatis Lodziensis. Folia Librorum” 2013, no 17, p. 89.

22 Ibidem.

23 Ibidem

24 H. Radlińska, Rola książki i biblioteki, "Rocznik Pedagogiczny - seria 2" 1924, vol. 2, p. 86, cited after: I. Kaczmarek, ibidem, p. 94.

25 B. Grosglikowa, Towarzystwo Bibliotek dla Dzieci. Historia, [in:] Biblioteki dla dzieci w Polsce, Warszawa 1934, p. 7.

26 Barbara Grosglikowa wrote in 1934 about the project of Ms Bornstein, while 50 years later M. Gutry assigned the initiative of library's establishment in 1925 to Helena Handelsmann, see: M. Gutry, Rozwój bibliotek dla dzieci w Polsce na przestrzeni pótwiecza, "Bibliotekarz” 1973, no 
Czerwijowski, the PL director of that time, agreed to separate 100 books from a general collection, which were offered on site twice a week for three hours to children aged 7-1227. The library found enormous popularity, and it had to limit its activity at BP request in February $1926^{28}$.

Three following reading rooms were opened in Warszawa in 1926 and 1927: at Karowa str., the Polish Hygenic Society premises, at Św. Wincentego str., a school building, and at Nowy Świat street, in the premises of the Polish Women Circle ${ }^{29}$. As the Public Library was taken over by the municipality in 1928, the previous section of libraries for children at the ZBP gained independence and transformed into Towarzystwo Bibliotek dla Dzieci [Libraries for Children Society, TBD], with its own statute and rules ${ }^{30}$. The statute stated:

Towarzystwo Bibliotek dla Dzieci ma na celu szerzenie czytelnictwa wśród dzieci i młodzieży przez organizowanie bibliotek dla nich przeznaczonych oraz przez współdziałanie z istniejącymi bibliotekami dla dzieci i młodzieży (§3). Biblioteki Towarzystwa użyczają bezpłatnie, zgłaszającej się młodzieży (bez różnicy płci, wyznania i narodowości) do czytania na miejscu książki, pisma periodyczne, mapy, atlasy, a także wszelkie inne pomoce naukowe. Książki mogą być wypożyczane i do domów o ile jest to przewidziane regulaminem poszczególnej biblioteki $(\S 4)^{31}$.

[TBD aims at reading promotion among children and youth, by organization of dedicated libraries and cooperation with existing children and youth libraries (§3). TBP libraries offer to the youth (regardless of gender, religion and nationality) books, journals, maps, atlases, as well as any other learning aids freely and onsite.]

TBD established on October 6, 1927, organized and supervised six libraries in Warsaw, managed by Barbara Groniowska (Grosglikowa) ${ }^{32}$, a director of one of them - it was her who developed and realized first library training just in $1927^{33}$. Libraries managed by TBD were working in school buildings in 1934

7-8, p. 201. Both Handelsmann and Gutry were members of the Founding Committee of the Association of Children's libraries. See: Statut Towarzystwa Bibliotek dla Dzieci, Warszawa 1928, p. 14. While M. Gutry in her article Warszawskie biblioteki dla dzieci assigned this initiative to both ladies, see: M. Gutry, Warszawskie biblioteki dla dzieci, [in:] Z dziejów książki i bibliotek w Warszawie. Praca zbiorowa, ed. by S. Tazbir, Warszawa 1961, p. 704. Therefore both ladies can be deemed as initiators of establishing this library.

27 B. Grosglikowa, Towarzystwo Bibliotek..., p. 7.

28 B. Grosglikowa, Towarzystwo Bibliotek dla Dzieci. Historia... p. 7. Probably children interfered the adults in using the library.

29 M. Gutry, Warszawskie biblioteki..., p. 705.

30 B. Grosglikowa, Towarzystwo Bibliotek..., p. 8.

31 Statut Towarzystwa Bibliotek..., pp. 3-4.

32 B. Grosglikowa together with her husband Kazimierz changed the name into Groniowski in 1932, see: Entuzjastki bibliotekarstwa dziecięcego, [ed. by B. Białkowska, with cooperation of W. Wasilewska], Warszawa 1999, p. 25.

33 B. Groniowska, Szkolenie czytelnika, "Bibliotekarz. Biuletyn Biblioteki Publicznej m.st. Warszawy poświęcony sprawom bibliotek publicznych" 1938, no 9, pp. 128-131. The year 1937 is given by Sława Łabanowska in Groniowska biographical article, see: eadem, Barbara Gro- 
(św. Wincentego, Otwocka, Narbutta, Zagórna, Czerniakowska, and Elbląska streets $)^{34}$. The crisis at the beginning of the 30 s. forced the organizers to decrease their opening time, from 6-9 hours in the beginning to 3-4 hours daily, with very high attendance, in particular during wintertime. These facilities worked as reading rooms with free access to shelves, each of them offered approximately 600 volumes. Their main goal was to develop children's adequate attitude towards books. The libraries were taken over by the Warsaw Public Library in April 1936, and the TBP itself transformed into Towarzystwo Przyjaciół Bibliotek dla Dzieci [Society of Friends of Children's Libraries], which helped in managing the library for children No 11 in Targówek district ${ }^{35}$. The number of public libraries for children in Warsaw increased to 11 facilities in that time. The third and the most well-known initiative was the one of $\mathrm{H}$. Radlińska. She proposed to present a book collection called "A Model Library for children" during the $4^{\text {th }}$ Bookselling Exhibition organized by Związek Księgarzy i Wydawców Polskich [the Polish Booksellers and Publishers Union]. The collection was accompanied by a 100 pages catalogue which as a tool facilitatated completion of book collections in school and children's libraries ${ }^{36}$. After closing the exhibition the Union gave this collection to the Warsaw Public Library Society under the condition that such a children's library would be organized. It was opened a year later, on November 25,1927 , in the Warsaw district Ochota, for all children aged 7-12. This date is perceived as the beginning of public libraries for children in Warsaw. The aforementioned "L'Heure Joyeuse" was also an organizational model for this facility, its internal structure and methods of work. M. Gutry, who managed it, wrote:

głównym celem biblioteki jest bezpłatne udostępnienie niezamożnym dzieciom przedmieścia dobrej książki rozrywkowej lub uzupełniającej naukę. Cel uboczny - to zbliżenie dzieci do książek przez wolny dostęp do półek z prawem dobrowolnego wyboru, umożliwienie korzystania z katalogów różnego typu, w atmosferze samorzutnie wytwarzającej się ciszy. Są to wszystko czynniki, które działają wychowawczo, podnosząc kulturę przez umiejętność obcowania z książką i jej użytkowania ${ }^{37}$.

[the main goal of a library is to offer indigent children a good book for entertainment or education, free of charge. The secondary goal is to bring children nearer to the books through free access to shelves, with a right of free selection, access to various catalogues, in an atmosphere of spontaneous silence. All these are educational factors, empowering culture through a skill of using the book.]

\footnotetext{
niowska (1889-1985), [in:] Entuzjastki bibliotekarstwa dziecięcego..., p. 27.

34 M. Gutry, Warszawskie biblioteki..., p. 705.

35 M. Gutry, Sekcja bibliotek dla dzieci Biblioteki Publicznej m. st. Warszawy, Warszawa 1939, p. 3.

36 J. Filipkowska-Szemplińska, M. Gutry, Katalog biblioteki wzorowej dla dzieci i młodzieży, foreword by H. Radlińska, Warszawa 1927, p. 127.

37 M. Gutry, Biblioteka Wzorowa..., p. 9.
} 
The Model Library for children was a branch of the Public Library. Books were organized in sections, their number growing thanks to a legal deposit. Popular-science books were organized according to the decimal classification. Gradually, different forms of work with books and children had been developed. For the youngest there was storytelling and reading aloud. The older readers were invited to lectures and contests. Children prepared albums, wrote their book reviews in a special notebook. In the school year 1933/1934 talks concerning the usage of books and library services while doing homework were started. The rules of the reading room consisted of four points: 1 . To wash hands before reading; 2 . To take care of the books; 3 . To respect silence; 4 . Not to come to the library if there is someone sick at home. Leaving the library, children marked their presence, throwing a colour disc into a box, depending on sex - yellow or blue. These were the rules for so-called guests-readers. Children visiting the library more often, who had been joining different works, were so-called permanent readers. They were allowed to set aside a book to read it the next day, to be on duty or to help a librarian in her work. Permanent readers had their cards, where their reading choices were registered. They had a meeting once a month when they discussed their activities of the previous month and settled a work schedule for the next.

Lending service for children was opened at the reading room in January 1933, without free access to shelves. Work was done with a small staff, 1,5 regular time and support of trainees from the 1-Year Library School at the Public Library, and from the Social and Educational Work Studies of the Free Polish University ${ }^{38}$.

The libraries tasks included: completion of the whole literature for children and youth, development of guidelines concerning children's library organization, verification of working methods being used in foreign libraries, and development of local ones, training of library students, research on children's reading, development of bibliography concerning children's libraries and children's literature. The facility was moved to an independent premise at Reja 9 str. in $1935^{39}$, and it became the No 1 Library for Children ${ }^{40}$.

There were four free of charge children's libraries in Warsaw in midNovember 1935, working as branches of the Warsaw Public Library. The (No 1) Model Library at Grójecka 93 str. (Ochota district) with a reading room and lending service; the No 2 Library at Karolkowa 45 str. (Wola district), offering

38 M. Gutry, Biblioteka Wzorowa dla Dzieci m. st. Warszawy, "Bibliotekarz. Biuletyn Biblioteki Publicznej m. st. Warszawy poświęcony sprawom bibliotek publicznych" 1934/35, no 3-4-5, pp. $37-40$.

39 Teatr Ochota (a theatre) is located in this building nowadays.

40 See: [online] https://pl.wikipedia.org/wiki/Biblioteka_Publiczna_w_Dzielnicy_Ochota_m.

st._Warszawy [retrieved at 13.09.2019]. 
only a reading room; the No 3 library at Piekarska 11 str. (Stare Miasto district) as a reading room (this facility was taken over by the city from the Public Libraries Society, together with other libraries for adults managed by this organization), and the No 4 Library at Felińskiego 15 str. (Żoliborz district), offering also only a reading room.

Sixteen such libraries - reading rooms had been opened in Warsaw until the war outbreak, eight of which were located in school buildings, and the rest on other premises. Such a large number of libraries caused that the Public Library authorities established a separate Libraries for Children Section in the school year 1936/1937 ${ }^{41}$. It consisted of the central, located at Koszykowa str., and its branches. Works were realized in three main areas: 1. Support for libraries (evaluation and reviews of books to be purchased, librarians meetings, visits in libraries); 2. Information and training (guidelines concerning work methods, lectures, trainings); 3. Museum - transformed later into the Children's Book Museum (devel-opment of a bibliography of children's books published since 1824 and materials concerning children's reading interests) ${ }^{42}$.

\section{Presentation of public libraries for children in the interwar Warszawa would be incomplete without mentioning three other initiatives.}

Towarzystwo Bibliotek Powszechnych w Warszawie [Public Libraries Society in Warsaw] established its own library in $1928^{43}$. As mentioned above, it was located in Stare Miasto district, Piekarska 11 str. It was organized according to American models, free of charge, with free access to shelves. It offered 20 seats, which with the number of visits about 50 children per day forced more than half of the readers to read on a floor. High frequency caused a limitation of enrolling new readers, as well as the visit time to two hours per day per individual. It was here noted that users of children's libraries became active readers of libraries for adults ${ }^{44}$. As mentioned above, this facility was also taken over by the Warsaw Public Library, like those of the Libraries for Children Society, in April $1935^{45}$.

\footnotetext{
${ }_{41}$ M. Gutry, Sekcja bibliotek..., p. 4.

42 M. Gutry, Sekcja bibliotek dla dzieci Biblioteki Publicznej m. st. Warszawy, Warszawa 1939 pp. 4-7.

43 The Public Libraries Society in Warsaw was established in 1922, in the result of joining the Reading Rooms Section of the Warsaw Charitable Society, the Warsaw Reading Rooms Society, and the Public Library Society, becoming the largest library institution in the capital of that time, managing 24 facilities in total in 1923, see: Towarzystwo Bibliotek Powszechnych w Warszawie. Sprawozdanie 1923-1927, ed. by. W. Dąbrowska, Warszawa 1928, p. 9.

44 M. Gorzechowska, Towarzystwo Bibliotek Publicznych w Warszawie, [in:] Biblioteki dla dzieci w Polsce, Warszawa 1934, p. 15.

45 M. Gutry, Rozwój bibliotek..., p. 203.
} 
Thanks to that the libraries had stable funds (coming from the municipal council), and they avoided liquidation.

Another initiative is the library of the Żoliborz branch of Robotnicze Towarzystwo Przyjaciół Dzieci [Workers Society of Friends of Children, RTPD], established in 1930. It was organized and managed by Maria Arnoldowa, who cooperated with M. Gutry, chief of the Model Library. In the RTPD Library books were collected in a lending service opened three times a week in the afternoons, 2,5 hours per day, and then in a reading room opened in April 1933, opened daily in the afternoons, 4.00-7.00 p.m. The book collection amounted to 1039 works at the end of 1933. The reading room was organized like the Model Library ${ }^{46}$, with free access to shelves, direct contact with a book, independent choice, individual approach to a reader. Arnoldowa valued cooperation with children's parents in library work, as well as the rule of free choice consisting of four elements - independent application to a library, visiting it when a reader wants it and for how long he/she does, free choice of a book. All readers were treated the same, regardless of what they read ${ }^{47}$. A children's librarian's task was a good knowledge of children's literature. He/ she was also to be an educator knowing children, their level of development, the potential of perception, interests and needs. The Reading Room Friends Circle was established in the library in $1934^{48}$. Work was guided by respect for a child and knowledge of his/her individuality. Binding rules included: silence, notification of attendance, and not disturbing others in reading ${ }^{49}$.

The third initiative was the Saint Theresa of Baby Jesus Library for Children, so-called "Andrusarnia", established in 1931 at Biblioteka Wiedzy Religijnej [Library of Religious Knowledge]. Irena Tyszkiewiczowa, its organizer, described its beginnings as follows:

W kwietniu 1931 r. przyszedł biedny chłopczyk prosić o książkę do Biblioteki i dostał książkę odłożoną na taki specjalny wypadek. Następnego dnia bibliotecznego przyszło 3 dzieci, potem 11, następnie 33. W rok potem było 600 zapisów, w 2 lata 1400, a obecnie jest ich $2295^{50}$.

[A poor boy came to ask for a book to the Library in April 1931, and he received the one put aside for such a special occasion. Another 3 children came next day, then 11, then 33. 600 children registered within a year, 1400 within two years, and now there are 2295 readers.]

46 M. Arnoldowa, Biblioteka Robotniczego Towarzystwa Przyjaciót Dzieci, [in:] Biblioteki dla dzieci w Polsce, Warszawa 1934, p. 14.

47 Entuzjastki bibliotekarstwa dziecięcego..., p. 38.

48 Ibidem, p. 39.

49 Ibidem, p. 38

50 E. Przybył-Sadowska, Biblioteka Wiedzy Religijnej w warszawie (1919-1939), “Z Badań nad Książką i Księgozbiorami Historycznymi” 2016, no 10, p. 217. 
The library was the property of the "Laski work", and was run by social forces as a free lending service, open twice a week - on Tuesdays for boys, and on Thursdays for girls, 4.00-6.30 p.m. Its collection amounted to more than 2000 volumes, and was used by more than 2300 children $^{51}$. Books "of different genre were collected, excluding those awakening instincts of cruelty and race, class and national hatred, with particular regard for the books that shape the character and develop love to God, homeland, family, school, nature, and everything that lives" 52 . "Andrusarnia" was organized in such a way that children can behave absolutely freely there. There was no library desk there, separating children from books. "They only had to bring a written agreement from their parents, which was very much observed. If it appeared to be a problem for a few of them because some parents could not write such a letter, countess Tyszkiewiczowa wrote such a letter by herself, and the parents had only to sign it. Children's literature was selected as carefully as that for the adults" ${ }^{\prime 3}$. In 1939, when the library was closed by the Germans, the book collection amounted to more than 3000 volumes and almost 50 journal titles ${ }^{54}$.

In 1938, just before the war, M. Gutry - chief of the children's libraries section at the Warsaw Public Library of that time, wrote:

Na zakończenie zachodzi pytanie w jakim kierunku powinna zmierzać praca bibliotek dziecięcych: 1) należałoby pomnożyć liczbę bibliotek dziecięcych do 60,2) zorganizować przy czytelniach dziecięcych wypożyczalnie, 3) przerzucić część prac technicznych na centralę [...], 4) prowadzić systematycznie, wykonywane dotychczas dorywczo, prace muzealne, 5) podjąć w niektórych punktach prace badawcze ${ }^{55}$.

[Finally, there is a question in which direction children's libraries work should go: 1) they should be multiplied up to 60 facilities; 2) lending services should be opened at children's reading rooms; 3) move a part of technical works to the central [...]; 4) museum works should be done systematically, instead of sporadically ; 5) start research works in selected areas.]

The author was aware that "realization of the projects, the scope of works, their good organization and results would depend on funds to a large extent" ${ }^{\text {. }}$.

There is little data concerning libraries' functioning during World War II. After the break of the September campaign and capitulation of Poland in October 1939, seven children's libraries were opened in Warsaw, and another one in December (one burnt, one was damaged by a bomb, four were taken

\footnotetext{
51 I. Tyszkiewiczowa, B-ka dla dzieci św. Teresy od Dzieciątka Jezus, [in:] Biblioteki dla dzieci w Polsce, Warszawa 1934, p. 15.

52 Ibidem.

53 E. Przybył-Sadowska, Biblioteka Wiedzy religijnej..., p. 218.

54 Ibidem, p. 219.

55 M. Gutry, Sekcja bibliotek..., p. 10.

56 Ibidem.
} 
over by German army) ${ }^{57}$. The next four were open in the years 1940-1941, there were finally 12 children's libraries in total. They had been working with great difficulty until August 1942, when they were suspended by the occupant authorities order, and finally closed in March 1943. Only one library survived until the outbreak of the Warsaw Uprising, managed by volunteers and changing locations RTPD Library in Żoliborz ${ }^{58}$.

\section{Other cities}

A few libraries were opened in other Polish cities. For instance, the Municipal Children's library in Dąbrowa Górnicza was opened in November 1929, modelled after the Model Library in Warszawa ${ }^{59}$. The children's library in Torun, also based on the Warszawa facility, was opened in 1933, joined with a community center under a common name Klub Dziecięcy (Children's Club) ${ }^{60}$.

Towarzystwo Czytelni Ludowych [the People's Libraries Society, TCL] established a separate children's library at the Karol Miarka Public Library in Katowice in November 1934. A model reading room for children was opened on May 3, 1935. The book collection amounted to 760 books and a few journal titles. The reading room was described in the "Oświata Polska" [Polish Education] periodical as "a children's paradise" visited by 200-300 readers daily ${ }^{61}$. On the other hand, the first children reading room was opened in Poznan on October 11,1935 , to celebrate the $75^{\text {th }}$ anniversary of TCL establishment. It occupied one room with 72 seats for the readers, with more than 1000 volumes, including either picture books for small children or historical and popular-science works, poetry, dramas, and religious publications ${ }^{62}$.

On initiative of Bronisława Bobrowska, President of Towarzystwo Przyjaciół Dzieci [Society of Friends of Children], a free of charge public library for children was opened in 1931 in the Podgórze district in Kraków ${ }^{63}$. This facility was also organized just like the Model Library in Warsaw. Supported by the Society funds, it fought against financial deficiencies and misunderstanding

57 M. Gutry, Rozwój bibliotek..., p. 205.

58 Ibidem, p. 207.

59 I. Burska, Biblioteka dla dzieci w Dąbrowie Górniczej, "Bibliotekarz. Biuletyn Biblioteki Publicznej m. st. Warszawy poświęcony sprawom bibliotek publicznych" 1934/35, no 3-4-5, pp. $42-43$.

60 S. Mąkołówna, Klub dziecięcy w Toruniu, "Bibliotekarz. Biuletyn Biblioteki Publicznej m.st. Warszawy poświęcony sprawom bibliotek publicznych" 1934/35, no 3-4-5, p. 43.

${ }_{61}$ J. Juzoniowa, Biblioteka $i$ Czytelnia T.C.L dla dzieci i młodzieży w Katowicach, "Oświata Polska. Organ Wydziału Wykonawczego Polskich Towarzystw Oświatowych” 1935, no 3, p. 42.

62 Kronika, "Bibliotekarz. Biuletyn Biblioteki Publicznej m. st. Warszawy poświęcony sprawom bibliotek publicznych" 1935/36, no 7, p. 98

63 H. Piwowarowa, Biblioteka dziecięca w Krakowie, "Bibliotekarz. Biuletyn Biblioteki Publicznej m.st. Warszawy poświęcony sprawom bibliotek publicznych" 1935/36, no 1, p. 6 . 
of the core of its activity among schools' directors, which resulted in a ban of children attending the library ${ }^{64}$. The last city where a children's library was organized was Radom. The circle of the Polish Educational Society run a library - reading room for children from primary schools in 1936 . The fee for using it was 0,3 PLN.

There were 27 active libraries for children in Poland until the war outbreak in general, located in big cities mostly. They were mostly related to education and people's movement, then their organization and funding were taken over by municipal councils. Their goal was to promote education among poorer social classes, care for children, education of a conscious citizen. Creation of such facilities in other locations were encouraged ${ }^{65}$. M. Gutry presented a detailed cost analysis of organizing such a small reading room for children, and a list of books for the smallest facility in her book ${ }^{66}$.

Creators of public libraries for children came from education activists, facilities they organized were of democratic character, with their education and upbringing functions emphasized. The following should be mentioned as the most deserving: M. Gutry, B. Groniowska, Jadwiga Filipkowska-Szemplińska, J. Borsteinowa, M. Arnoldowa, Irena Augustyniak and obviously H. Radlińska, who started systematic education of the staff for public libraries for children at the library course she opened at the Social and Educational Work Studies, the Free Polish University. This is Radlińska who gathered around herself and the ideas she promoted a group of "enthusiasts of children's librarianship" ${ }^{67}$. Contacts with foreign libraries and competent adaptation of foreign models to domestic potentials and needs were also important for the development of libraries in Poland.

The works had begun from scratch after World War II, the libraries had been established according to pre-war guidelines:

Już 21 lutego 1945 r. została otwarta Biblioteka dla dzieci Robotniczego Towarzystwa Przyjaciół Dzieci. 24 kwietnia 1945 r. Łódź uruchomiła I Wypożyczalnię dla Dzieci i Młodzieży, a 26 lipca została oddana do użytku Biblioteka dla Dzieci - filia Biblioteki Publicznej m.st. Warszawy. [...] Pod koniec 1945 r. było czynnych 9 placówek: 2 w Łodzi, 4 w Warszawie, po jednej w Radomiu, Tarnowie i Włocławku ${ }^{68}$.

[Just on February 21, 1945, the Children's Library of RTPD was opened. Łódź opened the No 1 Library for Children and Youth on April 24, 1945, and the Children's library - branch of the Warsaw Public Library was opened on July 26. [...] Nine facilities were active at the end of 1945: 2 in Łódź, 4 in Warszawa, and in Radom, Tarnów and Włocławek 1 each.]

64 Ibidem.

65 J. Bornsteinowa, Biblioteki..., p. 180.

66 M. Gutry, Rola i organizacja bibliotek..., pp. 17-24. The cost analysis amounted to 1019 PLN, and the smallest book collection consisted of 66 book titles.

67 Entuzjastki bibliotekarstwa dziecięcego..., p. 8.

68 M. Gutry, Rozwój bibliotek..., p. 207. 
This first, post-war period of the first reconstruction and then systematic development of public libraries for children ended in 1957, when the Ministry of Culture and the Arts introduced Guidelines concerning the organization of public libraries for children ${ }^{69}$ with its decision on July 20. Comparison if its content with the assumptions for work of pre-war libraries can prove that despite changed rhetoric, they survived historical turmoil. It is also important that the Guidelines were developed by M. Gutry, who worked in the Ministry until $1954^{70}$.

The following should be recognized as successes of the of pre-war public libraries for children :

- distinction of children's librarianship from a general one;

- recognition of the need for special education of librarians working with children;

- development of new forms of work - free access to shelves, many different ways of book promotion and usage;

- development of library training methods undertook also by libraries for adults and school libraries;

- international contacts, systematic continued education ${ }^{71}$.

\section{Conclusions}

Just as there were various paths leading to Poland regaining independence in November 1918, so were various initiatives aiming at the promotion of children's reading by establishing special libraries for children. They benefited from tradition and experiences of their predecessors. After all, books and education were one of the elements of the struggle for independence. There was a colourful mosaic of the entities of different sizes and variety which organized a child's access to a book (a good one - as it should be mentioned). The main center in this range was Warszawa, with the implemented idea of a library - reading room, where an education program could be realized. Models of American libraries for children, adapted from French, Belgian, and Danish experiences, influenced the thinking of such facilities in Poland for many years ahead. The Model Library in Warszawa became a cradle of Polish children's librarianship. Evaluation and selection of adequate children's book, implementation of diversified forms of reading promotion and development, observation and analysis of children and youth reading preferences, information, advisory, and librarians training

${ }^{69}$ Wskazówki w sprawie organizacji bibliotek dla dzieci i księgozbiorów dla dzieci w publicznych bibliotekach powszechnych. Załacznik do pisma Nr B-IV-3/22/57 z dnia 20 lipca 1957 r., [in:] T. Zarzębski, Przepisy prawne dla bibliotek powszechnych, Warszawa 1965, pp. 67-74.

70 Entuzjastki bibliotekarstwa dziecięcego..., p. 22.

71 M. Gutry, Rozwój bibliotek..., p. 204. 
- internships for librarianship students - became a priority. Carefully selected book collection was to support the process of education and the internal development of children ${ }^{72}$. The idea of a library as place of a child meeting a book and beauty, supporting the education process through the awakening of individual interests, activities, and independence in knowledge development was realized. The situation in Poland was also influenced by general global and European phenomena, achievements of psychology, pedagogy (among others Jean Piaget, Janusz Korczak, Stefan Baley), focusing attention on the youngest needs, although that of a city child the most often. Ellen Key named the $20^{\text {th }}$ century with reason "a century of a child", which was reflected in the organization of separated, intended for children, free of charge public libraries.

Translated by Matgorzata Kisilowska

\section{References}

Arnoldowa M., Biblioteka Robotniczego Towarzystwa Przyjaciół Dzieci, [in:] Biblioteki dla dzieci w Polsce, Warszawa 1934, p. 14.

Augustyniak J., Biblioteki miejskie w Łodzi. Dwuletnia opieka samorzadu, "Dziennik Zarządu m. Łodzi" 1924, no 48 (271), pp. 1-3.

Augustyniak J., Nowe formy organizacji czytelnictwa $w$ zastosowaniu do miejskich bibliotek dziecięcych, "Dziennik Zarządu m. Łodzi” 1928, no 18 (445), pp. 289-291.

Augustyniakowa I., Biblioteki dziecięce $w$ Lodzi. Historia $i$ stan obecny, "Bibliotekarz. Biuletyn Biblioteki Publicznej m. st. Warszawy poświęcony sprawom bibliotek publicznych" 1934-1935, no 3-4-5, pp. 29-33

Augustyniakowa I., Biblioteki dziecięce w Łodzi. Historia i stan obecny, [in:] Biblioteki dla dzieci w Polsce, Warszawa 1934, pp. 3-7.

B.J. [Bornsteinowa Jadwiga], Biblioteka dla dzieci w Warszawie, "Bluszcz. Pismo tygodniowe ilustrowane dla kobiet" 1926, no 6, pp. 161-162.

Biblioteki dla dzieci w Polsce, Warszawa 1934.

Bornsteinowa J., Biblioteki dla dzieci, "Praca szkolna. Dodatek miesięczny do Głosu Nauczycielskiego poświęcony sprawom pedagogiczno-dydaktycznym w związku z praktyką szkolną" 1927, no 5, pp. 177-180.

Burska I., Biblioteka dla dzieci w Dąbrowie Górniczej, "Bibliotekarz. Biuletyn Biblioteki Publicznej m. st. Warszawy poświęcony sprawom bibliotek publicznych” 1934/35, no 3-4-5, pp. 42-43.

Entuzjastki bibliotekarstwa dziecięcego, [ed. by B. Białkowska, with cooperation of W. Wasilewska], Warszawa 1999.

Filipkowska-Szemplińska J., Gutry M., Katalog biblioteki wzorowej dla dzieci i młodzie$\dot{z} y$, foreword by H. Radlińska, Warszawa 1927.

72 The goals listed by Radlińska in the introduction to the Model Library Catalogue. 
Gorzechowska M., Towarzystwo Bibliotek Publicznych w Warszawie, [in:] Biblioteki dla dzieci w Polsce, Warszawa 1934, p. 15.

Grabowska D., Rozwój sieci bibliotek dziecięcych w Polsce. Wybrane problemy, [in:] Megabiblioteki. Wybrane tendencje w bibliotekarstwie publicznym, ed. by D. Pietrzkiewicz, E.B. Zybert, Warszawa 2015, pp. 49-61.

Groniowska B., Szkolenie czytelnika, "Bibliotekarz. Biuletyn Biblioteki Publicznej m. st. Warszawy poświęcony sprawom bibliotek publicznych” 1938, no 9, pp 128-131.

Grosglikowa B., Towarzystwo Bibliotek dla Dzieci. Historia, [in:] Biblioteki dla dzieci w Polsce, Warszawa 1934, pp. 7-8.

Gutry M., Biblioteka Wzorowa dla dzieci m. st. Warszawy, [in:] Biblioteki dla dzieci w Polsce, Warszawa 1934, pp. 9-14.

Gutry M., Biblioteka Wzorowa dla dzieci m. st. Warszawy, "Bibliotekarz. Biuletyn Biblioteki Publicznej m. st. Warszawy poświęcony sprawom bibliotek publicznych" 1934/35, no 3-4-5, pp. 37-40.

Gutry M., Panu Czerwijowskiemu sprawozdanie z mojej pierwszej podróży bibliotekarskiej. Dn. 10 V 29, p. 13. The document (typescript) available in the Children's Book Museum, the Warsaw Public Library, sign. B.027.625.

Gutry M., Rola i organizacja bibliotek dla dzieci i młodzieży, Warszawa 1928.

Gutry M., Rozwój bibliotek dla dzieci w Polsce na przestrzeni pótwiecza, "Bibliotekarz" 1973, no 7-8, pp. 200-209.

Gutry M., Sekcja bibliotek dla dzieci Biblioteki Publicznej m. st. Warszawy, Warszawa 1939.

Gutry M., Warszawskie biblioteki dla dzieci, [in:] Z dziejów książki i bibliotek $w$ Warszawie, ed. by S. Tazbir, Warszawa 1961, pp. 704-725.

Ha. Fa. [Handelsmann Helena], Czytelnia dla dzieci w Paryżu, "Bluszcz. Pismo tygodniowe ilustrowane dla kobiet" 1925, no 2, pp. 39-40.

Juzoniowa J., Biblioteka i Czytelnia T.C.L. dla dzieci i młodzieży w Katowicach, “Oświata Polska. Organ Wydziału Wykonawczego Polskich Towarzystw Oświatowych” 1935, no 3, pp. 41-42.

Kaczmarek I., Biblioteki oświatowe i publiczne w Lodzi w dwudziestoleciu międzywojennym, “Acta Universitatis Lodziensis. Folia Librorum” 2013, no 17, pp. 75-95.

Kołodziejska J., Publiczne biblioteki samorządowe w okresie międzywojennym, Warszawa 1967.

Kronika, "Bibliotekarz. Biuletyn Biblioteki Publicznej m. st. Warszawy poświęcony sprawom bibliotek publicznych" 1935/36, no 7, pp. 98-99.

Maack M.N., L'Heure Joyeuse, the First Children's Library in France: Its Contribution to a New Paradigm for Public Libraries, "The Library Quarterly: Information, Community, Policy" 1993, vol. 63, no 3, pp. 257-281.

Mąkołówna S., Klub dziecięcy w Toruniu, "Bibliotekarz. Biuletyn Biblioteki Publicznej m. st. Warszawy poświęcony sprawom bibliotek publicznych” 1934/35, no 3-4-5, p. 43. 
Nagórska I., Początki czytelnictwa dzieci i młodzieży w Łodzi, “Bibliotekarz” 1972, no 1112, pp. 350-356.

Piwowarowa H., Biblioteka dziecięca w Krakowie, "Bibliotekarz. Biuletyn Biblioteki Publicznej m. st. Warszawy poświęcony sprawom bibliotek publicznych” 1935/36, no 1, pp. 6-7.

Przybył-Sadowska, E., Biblioteka Wiedzy Religijnej w Warszawie (1919-1939), “Z Badań nad Książką i Księgozbiorami Historycznymi” 2016, vol. 10 pp. 211-227.

Radlińska H., Rola książki i biblioteki, "Rocznik Pedagogiczny - seria 2" 1924, vol. 2, pp. 63-92.

Statut Towarzystwa Bibliotek dla Dzieci, Warszawa 1928, p. 14.

Towarzystwo Bibliotek Powszechnych w Warszawie. Sprawozdanie 1923-1927, ed. by W. Dąbrowska, Warszawa 1928

Tyszkiewiczowa I., B-ka dla dzieci św. Teresy od Dzieciątka Jezus, [in:] Biblioteki dla dzieci w Polsce, Warszawa 1934, p. 15.

W 50-lecie powstania pierwszej w Polsce biblioteki publicznej dla dzieci i młodzieży 19221972. Katalog wystawy, [compiled by I Nagórska], Łódź 1972, p. 25.

Wróblewski J., Działalność Towarzystwa Czytelń Ludowych w Poznaniu na rzecz ofiar wojny (1914-1918), "Bibliotekarz" 1973, no 4, pp. 110-115.

Wskazówki w sprawie organizacji bibliotek dla dzieci i księgozbiorów dla dzieci w publicznych bibliotekach powszechnych. Załacznik do pisma $\mathrm{Nr} B-I V-3 / 22 / 57$ z dnia 20 lipca 1957 r., [in:] Zarzębski T., Przepisy prawne dla bibliotek powszechnych, Warszawa 1965 , pp. 67-74. 